\title{
Effects of Semantic Feature Analysis Treatment on Landmark Naming in Individuals with Subjective Memory Impairment
}

\author{
Sang Eun Lee, Jee Eun Sung, Eunha Jo \\ Department of Communication Disorder, Ewha Womans University, Seoul, Korea
}

Correspondence: Jee Eun Sung, PhD Department of Communication Disorders, Ewha Womans University, 52 Ewhayeodae-gil, Seodaemun-gu, Seoul 03760, Korea Tel: $+82-2-3277-2208$

Fax: $+82-2-3277-2122$

E-mail: jeesung@ewha.ac.kr

Received: January 5, 2021

Revised: April 13, 2021

Accepted: April 28, 2021

This work was supported by the Ministry of Education of the Republic of Korea and National Research Foundation of Korea (NRF-2019R1A2C1089280).

This article is based on the master's thesis of the first author.

\begin{abstract}
Objectives: This study was carried out to investigate the effects of Semantic Feature Analysis (SFA)-plus treatment on landmark naming difficulties of the elderly with subject memory impairment (SMI). Methods: Twenty-six Korean individuals aged 60 or older with SMI participated in this study, eleven participants were in the intervention group and fifteen individuals who matched their age and years of education made up the control group. The landmark naming intervention consisted of a total of 9 steps based on SFA, presenting photo stimuli of famous places in Korean or abroad. The intervention used in this study was performed 1:1 with the subject for 60 minutes per session with 16 sessions. Visual stimulation, semantic categories, and semantic features such as geographic location, were applied to promote the performance of naming. The researcher provided tasks and clues to facilitate activation of the semantic and phonological information of landmark names. Results: Results demonstrated that there were significant increases in the performance of the trained and untrained place proper names among the intervention group. There was no generalization effect of the object naming. Conclusion: The current study suggested that the naming treatment using place names was effective in activating the semantic network, facilitating phonological information output, and enhancing landmark naming abilities in people with subjective memory decline.
\end{abstract}

Keywords: Semantic Feature Analysis (SFA) treatment, SMI, Proper noun naming
해마다 증가하는 치매(dementia) 환자로 인한 사회적 비용이 급 증하여 2050년에는 43조 2천억 원에 달할 것이라는 추정이 나오는 등 치매에 대한 국가 차원의 대응을 요구하는 우리 사회의 목소리 가 높다(Ministry of Health and Welfare, 2019). 치매의 조기 진단 에 대한 인식 또한 높아짐에 따라 인지 기능 변화에 대한 노인 본인 의 자기 평가(self-assessment) 및 자기 보고를 연구하는 시도가 계 속되고 있다. 이러한 시도의 하나로 주관적 기억장애(subject memory impairment; Tobiansky, Blizard, Livingston, \& Mann, 1995)가 노년층의 인지 기능 손상 혹은 치매를 조기에 발견할 수 있는 변인 으로 주목받고 있다(Chin, Oh, Seo, Shin, \& Na, 2010). 주관적 기억 장애(subjective memory impairment, SMI)는 기억력 저하를 호소 하지만 객관적인 기억검사에서 이상이 발견되지 않는 노인의 상태 를 지칭한다(Tobiansky et al., 1995). Song과 Kang (2011)의 연구는
주관적 기억장애의 기준을 주관적으로 기억력 저하를 호소하지만 일상활동(activities of daily living, $\mathrm{ADL}$ )과 객관적인 인지 기능에 서 정상 범주의 수행을 보이는 사람들로 정의하고 있다. Jessen 등 (2014)은 이 용어를 전반적인 인지 기능의 저하까지 확장시켜 주관 적 인지저하(subjective cognitive decline, SCD)라는 개념을 제시하 고 있다.

기억력 등 인지 영역 전반의 기능 저하를 겪는 노년층은 특정 사 물이나 인물, 장소의 이름이 잘 떠오르지 않는 이름대기 어려움을 빈번히 호소한다(Mortensen, Meyer, \& Humphreys, 2006). 객관적 인 기억의 결함이 나타나지 않는 주관적 기억장애 집단을 대상으 로 한 이름대기 연구는 많지 않으나 경도인지장애(Mild cognitive impairment) - 치매 집단을 대상으로 의미기억(semantic memory) 의 손상에 초점을 맞춘 연구들이 기억저하와 이름대기 수행의 관 
련성을 보고하고 있다(Hodges, \& Patterson, 1995; Won, Yoon, \& $\mathrm{Na}, 2017)$. 기억체계에서 이름대기에서 가장 큰 중요도를 갖는 의미 기억(semantic memory)은 '대통령이 사는 곳은 청와대이다'와 같 이 사물이나 개념의 의미적 지식(semantic knowledge) 정보의 저 장과 관련이 있는 기억의 영역이다(Lee, 2000).

이름대기 능력은 일반적으로 대상자에게 그림 등의 목표 자극을 시각적으로 제시한 다음 자극의 이름을 말하도록 하는 대면 이름 대기(confrontation naming) 과제를 통하여 측정할 수 있는데 과제 중 대표적인 것이 보스턴이름대기검사(Boston Naming Test; Kaplan, Goodglass, \& Weintraub, 1983)이다. 노인의 이름대기 평가 점수 저하와 연령과의 연관성을 밝힌 다수의 선행연구들이 있다. Albert, Heller와 Milberg (1988), Feyereisen (1997)의 연구에서 70 세 이상 노인들이 그 이전 연령대의 성인들에 비해 대면 이름대기 수행 저하를 보인다는 결과를 보고했다. Connor, Spiro, Obler와 Albert (2004)의 연구는 20년 동안 30-94세의 정상 성인 236명에게 5 회의 보스턴이름대기검사(Boston Naming Test; Kaplan et al., 1983)를 실시하여 이름대기 정확도를 분석한 결과, 대상자들의 수 행력이 10 년마다 평균 $2 \%$ 의 감소를 보였으며 70 세 이후에 이름대 기 어려움이 뚜렷이 나타났다. 또한 50대 대상자들에게서도 이름 대기 능력의 미세한 감소가 나타나기 시작했다고 밝히고 있다. 이 와 같은 이름대기 어려움은 노인들의 구어 표현력에 제한을 주고 의사소통과 일상생활 전반에 큰 불편을 야기하는 요소가 될 수 있 다(Kim, Kang, Lee, Kim, \& Yoon, 2019; Lee \& Kim, 2011).

노화에 따른 이름대기 능력 저하를 규명하는 연구들은 첫째, 처 리속도이론(processing speed theory; Myerson, Ferraro, Hale, \& Lima, 1992; Salthouse, 1996)을 바탕으로 한다. 이 연구들은 노화 에 따라 감각, 인지, 언어처리 과정에서 일반적인 속도 저하(General Slowing)가 나타나고 이로 인해 이름대기 과제에서 반응속도가 유 의하게 느려진다고 설명하고 있다. 둘째, 전달손실가설(Transmission Deficit Hypothesis; Burke, MacKay, Worthley, \& Wade, 1991) 을 근거로 노화과정에 나타나는 이름대기를 설명하는 연구들이 있 다. 전달소실가설은 마디 구조 이론(Node Structure Theory)에 기 반한 것으로 언어 시스템을 어휘-의미(lexical-semantic) 마디 (node)와 음운(phonological) 마디가 위계적으로 연결된 구조라고 가정한다(Burke et al., 1991; Burke \& Shafto, 2004; Lee \& Lee, 2011; Neumann et al., 2009). 각 마디들은 연결된 다른 마디로부터 충분 한 양의 정보의 점화(priming)를 전달받아 활성화(activation)되고 이를 통해 마디가 표상하고 있는 정보가 인출된다. 노화로 인하여 마디 간 연결이 약해져 점화 전달 손실이 발생하면 음운 마디가 상 위의 어휘-의미(lexical-semantic) 마디로부터 충분한 점화를 받지
못하게 되어 정확한 음운 정보를 인출할 수 없게 된다.

위와 같은 전달손실가설을 기반으로 한 대면 이름대기 연구 중 에서 노년층의 이름대기를 촉진하는 단서 유형(의미적, 음소적)과 노년층이 보여주는 이름대기 오류 유형(의미적, 음소적)에 주목한 시도들이 있다. $\mathrm{Au}$ 등(1995)은 70세 이상의 대상자에게 음소 단서 (phonemic cue)의 효과가 그 이전의 연령대의 집단에 비해 유의하 게 크지 않다는 결과를 보고하였다. 목표 명사의 첫 음소 등을 제공 하여 이름 산출을 도와주는 음소 단서는 대면 이름대기의 처리경 로 상의 어휘-의미(lexical-semantic)와 음운(phonological) 마디의 연결 약화로 인한 음운 표상의 산출 실패에 적용되는 것이 효과적 이다. 그러나 70 세 이상 고령 집단은 어휘-의미와 음운 마디 사이의 연결 약화가 아닌 의미-어휘적 단계부터 점화 및 활성화가 되지 않 아음소 단서의 효과가 미미하다는 것이다.

노년층의 이름대기 어려움은 일반적인 사물을 가리키는 보통명사 (common noun)보다 사람 및 장소 등을 지칭하는 고유명사(proper noun)에서 더욱 빈번히 나타나는 것으로 알려져 있다(Burke et al., 1991). 청년층과 비교했을 때, 노년층이 보통명사에 보다 고유명사 이 름대기에 어려움이 유의하게 크게 나타나며(Robson, Marshall, Pring, Montagu, \& Chiat, 2004; Ross, McCoy, Coslett, Olson, \& Wolk, 2011), 고유명사에서 더 많은 설단현상(tip-of-the-tongue)을 경험한다(Evrard, 2002). 설단현상이란 말하고자 하는 대상의 이 름을 알고 있음에도 일시적으로 말이 혀끝에서 맴도는 이름대기 어려움을 의미한다(Brown \& McNeil, 1966; Burke et al., 1991). 설 단현상은 Levelt, Roelofs와 Meyer (1999)가 제시한 어휘산출모델 을 통해 설명될 수 있다. 어휘산출모델은 어휘인출(word retrieval) 이 개념화(conceptual stratum), 의미표제어 선택(lemma selection), 음운부호화(phonological encoding)의 세 단계로 이루어진 다고 가정한다. 의미표제어 선택은 정상적으로 수행되었으나 음운 부호화에 실패하였을 때 설단 현상을 경험하게 된다(Jo \& Sung, 2019; Kim et al., 2019). 노년층이 고유명사 이름대기에 더 취약한 이유를 고유명사 처리과정이 보통명사보다 더 복잡하는 점을 들어 설명하고 있다. Kay, Hanley와 Miles (2001)는 보통명사에 비해 고 유명사가 음절 수 등 음운적 복잡성이 크고 친숙도와 사용 빈도가 더 낮다고 설명하고 있다. 다른 연구에서 보통명사와는 달리 고유 명사는 지시대상이 의미적으로 유일한 관계(unique mapping)에 있다고 설명하고 있다. 또한 이름과 지시대상 간에 약하고 자의적인 (weak and arbitrary) 관계를 보이기 때문에 더 복잡한 어휘인출 과 정이 필요하다(Evrard, 2002; Robson et al., 2004).

경도인지장애 집단과 정상 노년층을 대상으로 사물, 유명인, 유 명건물 이름대기 능력을 비교한 연구에서 경도인지장애 집단은 세 
개 과제 모두에서 정상 노년층에 비해 유의하게 낮은 정반응률을 보였으며 사물 이름대기에 비하여 고유명사(유명건물 및 유명인) 이름대기의 수행력이 유의하게 낮았다(Ahmed, Arnold, Thompson, Graham, \& Hodges, 2008). 이 결과를 근거로 고유명사의 이름 대기 과제가 일반적인 인지 기능 검사 기준으로 선별하기 어려운 치 매 전 경도인지장애 단계의 의미기억 손상을 평가하기에 유용할 수 있다고 보고하였다. 또한 Kim 등(2010)의 연구는 정상 노인 집단과 경도인지장애 집단을 대상으로 유명인 이름대기와 사물 이름대기 를 실시하여 유명인 이름대기 과제에서 집단 간 유의한 차이를 보 고하였다. 그러나 사물 이름대기 과제에서는 집단 간 유의한 차이 를 보이지 않았다. 이 연구 결과는 정상 노년층과 경도인지장애를 구별하는 데 유명인 이름대기 능력이 더 민감한 영향을 주며 인물 고유명사에 관한 특유한 의미체계 처리과정을 시사하고 있다.

고유명사의 다른 범주인 건물, 도시 등의 유명장소 이름대기 (landmark naming)에 대한 선행연구도 고유명사 이름대기의 복잡 한 어휘인출 과정을 설명하고 있다. Tranel, Enekwechi와 Manzel (2005)은 자극의 시각적 복잡성, 이미지 일치도, 친숙도를 고려하여 세계 유명장소 사진으로 구성된 이름대기 검사를 개발하여 대상자 의 성별, 개인적 경험과 교육수준에 따른 유명장소 식별 과제 및 이 름대기 수행력의 특성을 보고하고 있다. 길 찾기 기능 및 지리적 지 식에서 우세를 보이는 남성이 유명장소 식별 과제에서 더 높은 수 행을 보였으나 이름대기에서 성별의 효과는 나타나지 않았다.

의미자질 분석(Semantic Feature Analysis, SFA) 중재는 어휘체 계에서 목표명사의 의미자질을 활용하여 명사 산출을 촉진하고, 다른 명사와의 비교 및 대조로 의미자질을 강화하고, 목표 단어가 포함된 의미적 네트워크를 활성화시키는 중재 방법이다(Boyle \& Coelho, 1995; Kang, Sung, \& Lee, 2015; Kiran \& Thompson, 2003; Mo, Sung, \& Jeong, 2015). SFA 중재는 외상성 뇌손상 환자, 실어증 과 치매 환자를 대상으로 적용되고 있으며, 다수의 연구들이 이름 대기 능력 향상에 일관적인 치료 효과가 있다고 보고하고 있다. Oh, Eom, Park과 Sung (2016)의 연구는 국내외에서 실시된 11개의 SFA 중재의 효과에 관하여 메타 분석을 실시하여 SFA 중재가 이름대기 치료에 긍정적인 효과가 있다는 사실을 밝히고 있다. 분석 결과, 중 재 항목에서는 중간에서 높은 수준의 효과크기가 산출되었으며 비 중재 항목과 자발화에서는 제한적인 일반화 효과를 보였고 표준화 검사에서는 유의한 언어능력 향상 효과가 나타난다고 밝히고 있다.

신경언어장애 환자를 대상으로 한 SFA 중재의 효과를 보고한 연 구들을 살펴보면, Law, Wong, Sung과 Hon (2006)의 연구에서는 3 명의 실어증 환자를 대상으로 SFA 중재를 실시하였으며 모든 대상 자에게서 사전보다 사후에 중재 명사 이름대기 정반응률이 높게
나타났다. 반면, 비중재 명사 이름대기 정반응률은 대상자 별로 상 이하였는데 한 명은 사전보다 사후에 비중재 명사 정반응률이 높 았으나 나머지 두 명은 사전 - 사후에 거의 차이가 없었다. Mo 등 (2015)과 Kang 등(2015)은 알츠하이머성 치매 환자를 대상으로 $\mathrm{SFA}$ 중재를 실시하였으며, 중재 명사에 대해서 중재 효과를 확인하 였으나 일반화 효과는 제한적인 것으로 보고하였다.

$\operatorname{Kim}$ 등(2019)은 55세에서 84세 사이의 장노년층 42 명을 대상으 로 한국판 보스턴이름대기검사(Korean version-Boston Naming Test, K-BNT; Kim, Kim, \& Na, 1997)를 실시하여 이름대기 정상 집 단과 비정상 집단을 구분하였으며, SFA 중재 전후에 K-BNT를 실 시한 후 정반응 수를 비교한 결과 중재 후 정상 집단과 비정상 집단 모두에서 K-BNT의 정반응 수가 증가하였다.

의미자질, 음운·철자 자질을 활용한 언어 중재를 실시하여 인물 과 장소의 고유명사 인출에 대한 중재 효과를 보고한 연구가 있다 (Minkina et al., 2013). 이 연구는 고유명사 이름대기의 손상을 보 이는 61 세의 좌측두엽 뇌전증 환자를 대상으로 장소 이름의 의미 자질, 음운·철자 자질을 활용한 언어 중재를 적용하였으며 그 결 과 의미 네트워크 활성화로 인한 고유명사 이름대기 수행 향상이 나타났다. 고유명사 이름대기 과정에 필요한 시각적 요소, 의미, 음 운, 철자, 조음운동 등의 전반적인 언어처리 과정에 기반을 둔 이 중 재는 고유명사의 언어적 속성을 활용하여 중재 단계를 구성하였다. 예를 들어 ‘에펠탑'이라는 하나의 실체(entity)를 이루고 있는 요소 로서 대상의 형태, 색깔, 높이 등의 시각적 자질, '파리에 있다, 3 층 이다' 등의 의미자질, 종성 'r'이라는 철자자질을 활용하였다.

본 연구는 선행연구(Kiran \& Thompson, 2003; Kang et al., 2015; Mo et al., 2015)의 SFA 중재를 기반으로 수정.보완하여 장소 고유명사의 시각적 자극, 의미범주, 의미자질 분석, 지리적 위치, 음 운-철자 단서 등의 요소가 적용된 SFA-plus 중재가 이름대기 수행 에 미치는 효과를 알아보고자 한다. 치매 등 병리적(pathological) 노화에 대한 높은 사회적 관심에 걸맞지 않게 정상 인지를 보이는 노년층 대상의 중재의 시행이나 효과성의 검증이 아직 매우 미비한 실정이다. 따라서 본 연구는 주관적 기억장애 노년층의 이름대기 능력 증진을 위하여 이들이 겪는 대표적인 언어적 어려움을 고유명 사 이름대기로 설정하여 언어 중재를 적용한 후, 중재 명사 이름대 기 수행력에 미치는 효과와 비중재 명사 및 표준화검사로의 일반화 효과를 규명하고자 한다.

본 연구는 주관적 기억장애 노년층의 이름대기 능력 증진을 위 하여 유명장소 고유명사 이름대기 중재의 효과를 확인하고자 하며 본 연구의 구체적인 연구문제는 다음과 같다.

첫째, 중재 전 · 후에 따라 중재집단과 통제집단 간 중재 명사 이 
름대기 수행력에서 유의한 차이가 있는가?

둘째, 중재 전 · 후에 따라 중재집단과 통제집단 간 비중재 명사 이름대기 수행력에서 유의한 차이가 있는가?

셋째, 중재 전 · 후에 따라 중재집단과 통제집단 간 표준화검사의 이름대기 수행력에서 유의한 차이가 있는가?

\section{연구방법}

\section{연구대상}

본 연구는 서울, 경기 및 충청 지역에 거주하는 만 60 세 이상의 노인 26명을 대상으로 실시하였다. 연령 분류 기준은 주관적 기억 력 및 인지 기능의 저하가 시작되는 연령을 60세로 규정한 Jessen 등(2014)의 연구에 근거하였다. 대상자들은 사전에 연구의 목적 및 절차에 대한 상세한 설명을 들은 다음 서면으로 연구 참여에 동의 하였다. 본 연구는 연구윤리위원회(IRB)의 승인을 받아 진행하였 다(ewha-202008-0006-01).

연구 대상자의 구체적인 선정 기준은 다음과 같다. (1)주관적 기억 감퇴 설문(Subjective Memory Complaints Questionnaire, SMCQ; Youn et al., 2008) 점수가 6점 이상으로 주관적 기억장애를 호소하 는 자, (2)건강선별설문지(Christensen, Multhaup, Nordstrom, \& Voss, 1991)를 실시하여 신경학적 손상 및 정신적 병력이 보고되지 않은 자, (3)한국형 간이정신상태 진단검사(Korean-Mini Mental State Examination, K-MMSE; Kang, 2006) 결과, 연령 및 교육수준 대비 $16 \%$ ile 이상의 정상 범위에 속하는 자, (4)서울신경심리검사 (Seoul Neuropsychological Screening Battery, SNSB-II; Kang, Jang, $\& \mathrm{Na}, 2012)$ 의 하위 검사인 서울언어학습검사(Seoul Verbal Learn- ing Test, SVLT)의 즉각회상 및 지연회상 점수가 연령 및 교육수준 대비 $16 \%$ ile 이상의 정상 범위에 속하는 자, (5)일상활동평가-복합 (Seoul-Instrumental Activities of Daily Living, S-IADL; 구형모 등 2004)에서 6점 미만으로 일상생활에 어려움이 없는 자, (6)한국판 노인우울척도 단축형(Korean version of the short form of Geriatric Depression Scale, SGDS-K; Cho et al., 1999) 점수에서 우울증을 의심할 수 있는 8점을 넘지 않은 자로서 한국어를 모국어로 하며 선별검사 중 검사자의 관찰을 통해 시·청지각에 이상이 없음을 확 인한 노인이다. 분산분석을 위한 대상자 수를 파악하기 위해서 $\mathrm{G}^{\star}$ Power 프로그램(Faul, Erdfelder, Buchner, \& Lang, 2009)을 이 용하여 검증력 .80 , 유의수준 .05, 효과크기 .30으로 산출한 결과, 24 명 이상의 대상자가 필요한 것으로 나타났다. 본 연구에는 총 26 명의 노인들이 참여하였으며, 이름대기 중재 참여 유무에 따라 중 재집단 11 명과 통제집단 15 명으로 나뉘어 구성되었다. 집단 구성 기 준은 중재에 참여할 수 있는 시점에 따라 중재 및 통제집단으로 구 분하였다. 사전 - 사후 평가 과제 및 중재는 2020년 8월부터 2020년 11 월 사이에 진행되었다.

두 집단 간 인구통계학적 특성과 선별검사 측정변수에서 차이가 있는지를 확인하기 위하여 기술통계, 독립표본 $t$-검정(independent samples t-test) 및 카이제곱 검정 $\left(\chi^{2}\right)$ 을 실시하였다. SNSB-II 규준 에 따라 정규 교육을 받은 경험이 없으나 문해력이 있는 대상자들 의 교육년수는 .5 로 규정하였다. 분석 결과, Table 1 과 같이 두 집단 간 연령, 교육수준, 인지 기능, 우울, 일상생활, 주관적 기억호소 등 의 선별검사 측정변수에서 통계적으로 유의한 차이가 없음을 확인 하였다 $(p>.05)$.

본 연구가 유명장소를 이름대기 중재 자극으로 활용한다는 측면

Table 1. Descriptive statistics and t test results from screening tests

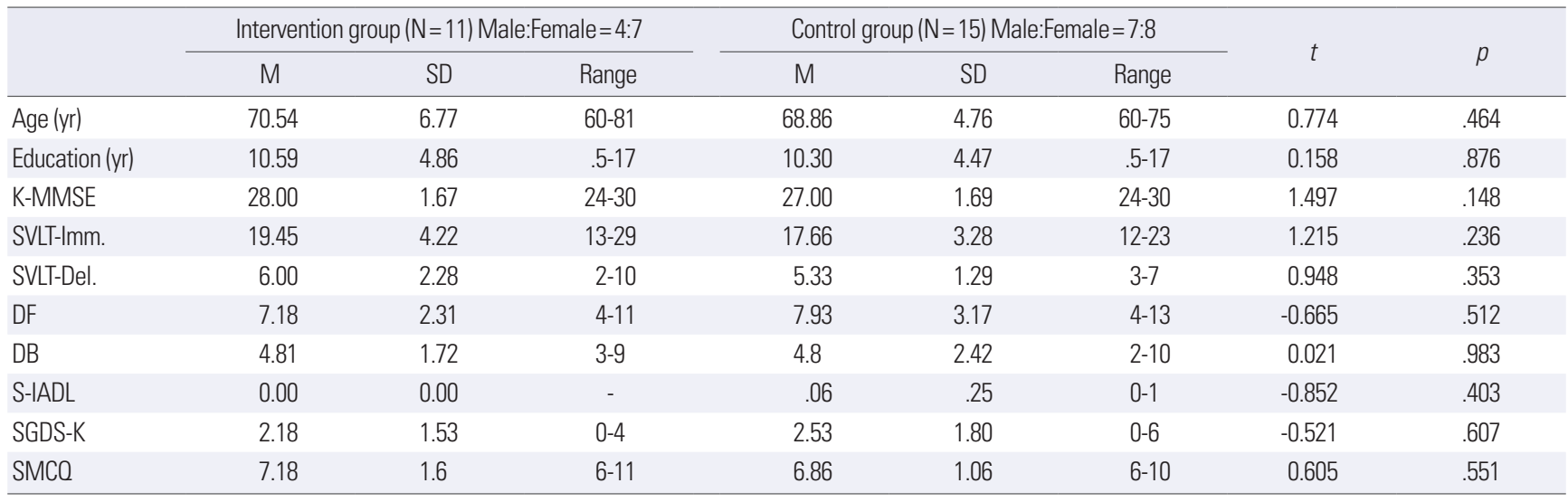

K-MMSE= Korean-Mini Mental State Examination (Kang, 2006); SVLT-Imm. = Seoul Verbal Learning Test (Kang et al., 2012) Immediate Recall; SVLT-Del. = Seoul Verbal Learning Test Delayed Recall; DF= Digit Forward Recall (Kang et al., 2012); DB=Digit Backward Recall (Kang et al., 2012); S-IADL=Seoul-Instrumental Activities of Daily Living (Ku et al, 2004); SGDS-K Korean Version of the Short Form of Geriatric Depression Scale (Cho et al., 1999); SMCQ=Subjective Memory Complaints Questionnaire (Youn et al., 2009). 
에서 최근 2 년간 국내·외 여행경험 빈도에 대한 사전조사를 실시 하여 집단 간 여행경험 빈도의 차이가 유의한지 살펴보았다. 그 결 과, Table 2와 같이 집단 간 여행경험 빈도에서 통계적으로 유의한 차이가 없음을 확인하였다( $p>.05)$.

본 연구의 사전평가 과제로 유명장소 이름대기 과제와 표준화검 사인 K-BNT를 실시하였다. 중재를 실시하는 목표명사(이하 중재 명사) 20 문항, 중재를 실시하지 않는 명사(이하 비중재 명사) 20 문 항의 두 개 과제로 나누어 실시하였다. 유명장소 이름대기 정반응 률(\%)과 K-BNT의 점수(범위: 0-60)를 측정변수로 사용하였다.

두 집단의 사전 이름대기 능력에 차이가 있는지를 확인하기 위 하여 기술통계 및 독립표본 $t$-검정(independent samples $t$-test)을 실시하였다. 분석 결과, Table 3 과 같이 두 집단 간 사전 평가 과제 실시 결과 이름대기 능력에서 통계적으로 유의한 차이가 없어 집단 간 통제가 적절히 이루어졌음을 확인하였다( $p>.05)$.

\section{SFA 중재 자극}

본 연구의 중재 명사를 선정하기 위하여 유명장소의 범주 설정과 자극 선정 기준은 선행연구들(Ahmed et al., 2008; Condret-Santi et al., 2014; Tranel et al., 2005)에 근거하였다. 중재 명사는 국내·해 외 범주로 나누어 세계 전역에서 선정하고 오랜 기간 동안 특정 지
역을 대표하는 상징물(enduring icons)로서 하나의 이름으로 산출 될 수 있는(namable) 유명장소의 이름을 기준으로 하였다. 『세계 에서 가장 경이로운 자연·문화 유산 100: 문명과 자연이 빚은 놀라 운 걸작들』 (Benthues et al., 2007), 『세계문화유산 100배 즐기기: 한국편』(Oh, 2015), '서울 빌딩 스토리'(ChosunBiz, 2016)에 수록 된 국내·외 유명장소를 참고하여 국내· 해외 2가지 범주로 각각 41 개, 29 개 총 70 개의 장소의 목록을 1 차로 작성하였다. 연구자와 시 각디자이너 1 명이 논의를 거쳐 Google 등의 인터넷 이미지 검색을 통하여 각 명사에 대한 컬러사진을 선정했다. 방송, 광고 등 미디어 에 일반적으로 노출된 친숙한 이미지를 중심으로 목표 장소의 전 체가 사진 중앙부에 단독으로 위치하는 주간에 찍힌 사진을 선정 기준으로 규정하였다.

1 차로 선정된 국내·외 사진 자극에 대하여, Snodgrass와 Vanderwart (1980)의 선행연구를 바탕으로 사진과 장소 이름이 얼마나 일 치하는지에 대한 이름 일치도(name agreement) 조사를 실시하였 다. 본 연구의 사진-이름 일치도 조사를 위하여, 평균 연령 36.3세 (범위: 23-49세)의 정상 성인 50명을 대상으로 Google 드라이브의 설문지를 통해 사진과 장소 이름을 동시에 제시하고 1점(매우 일치 하지 않음)-5점(매우 일치함)의 5점 척도로 일치도를 평가하도록 하였다. 측정된 일치도 점수의 평균(4.23)과 표준편차(0.36)를 기준

Table 2. $\chi^{2}$ test results from the travel experiences survey

\begin{tabular}{|c|c|c|c|c|c|c|}
\hline & \multicolumn{2}{|c|}{ Intervention group ( $\mathrm{N}=11$ ) } & \multicolumn{2}{|c|}{ Control group ( $N=15$ ) } & \multirow{2}{*}{$x^{2}$} & \multirow{2}{*}{$p$} \\
\hline & Frequency & $\%$ & Frequency & $\%$ & & \\
\hline \multicolumn{7}{|l|}{ Domestic } \\
\hline Never & 1 & 9.1 & 1 & 6.7 & 2.272 & .686 \\
\hline Once & 2 & 18.2 & 4 & 26.7 & & \\
\hline $2-3$ & 3 & 27.3 & 5 & 33.3 & & \\
\hline $4-5$ & 4 & 36.4 & 2 & 13.3 & & \\
\hline More than 6 & 1 & 9.1 & 3 & 20.0 & & \\
\hline \multicolumn{7}{|l|}{ Overseas } \\
\hline Never & 4 & 36.4 & 8 & 53.3 & 3.603 & .165 \\
\hline Once & 3 & 27.3 & 6 & 40.0 & & \\
\hline $2-3$ & 4 & 36.4 & 1 & 6.7 & & \\
\hline $4-5$ & 0 & 0 & 0 & 0 & & \\
\hline More than 6 & 0 & 0 & 0 & 0 & & \\
\hline
\end{tabular}

Table 3. $t$-test results from the pre-tests

\begin{tabular}{|c|c|c|c|c|c|c|c|c|}
\hline & \multicolumn{3}{|c|}{ Intervention group $(\mathrm{N}=11)$} & \multicolumn{3}{|c|}{ Control group ( $\mathrm{N}=15)$} & \multirow{2}{*}{$t$} & \multirow{2}{*}{$p$} \\
\hline & $M$ & SD & Range & $M$ & SD & Range & & \\
\hline Trained items (\%) & 52.27 & 23.49 & $20-85$ & 46.66 & 23.57 & $15-80$ & .600 & .554 \\
\hline Untrained items (\%) & 49.54 & 24.74 & $15-90$ & 46.66 & 23.65 & $5-85$ & .301 & .766 \\
\hline K-BNT (scores) & 49.18 & 6.52 & $38-58$ & 44.86 & 7.56 & $34-56$ & 1.520 & .142 \\
\hline
\end{tabular}

K-BNT = Korean version-Boston Naming Test (Kim, Kim, \& Na, 1997). 
으로 - $0.3 \mathrm{SD}$ 이상의 범위에 속하는 국내 25 개, 해외 17 개 총 42 개 를 선정하였다. 선정된 국내 장소 중에서 사전 - 사후 평가 과제인 K-BNT의 42 번 문항과 중복된 '첨성대'와 유명장소 이름대기 과제 의 연습문항으로 제작할'남대문'을 제외하여 총 40 개의 중재 자극 을 최종 선정하였다.

본 연구는 중재 및 일반화 효과를 비교하기 위해 40 개의 자극을 1) 중재를 실시하는 중재 명사와, 2) 중재를 실시하지 않는 비중재 명사 2세트로 나누어 구성하였다. 선행연구(Condret-Santi et al., 2014)와 『한국어 명사의 화제 의미관계 네트워크』(Kang, 2017)을 근거로 장소 명사의 의미자질을 범주(국내·외 명소), 위치(서울, 경 주, 부산, 유럽, 미국, 아시아), 기능(국가 주요시설, 기념물 및 문화 역사유적, 자연명소)으로 설정하였다.

중재 명사 및 비중재 명사 자극이 의미적 연관성을 이루도록 하 나의 자극에 하나의 자극을 대응시키는 방식으로 분류하여 Appendix 1 과 같이 중재.비중재 명사 간의 균형을 고려하였다. 예를 들어, '경주의 관광지'라는 의미적 연관성을 가진 '석굴암'과 ‘불국 사'를 대응시켜 각 세트에 하나씩 배치하였다. 해외 장소로는 '이집 트에 위치한 고대문명 유적'이라는 의미적 연관성을 가진 '스핑크 스'와 ‘피라미드'를 짝지어 각 세트에 배치하였다. 또한, 중재.비중재 명사의 첫 음소와 음절 수의 균형을 이루도록 분류하였다. 선정된 40 개의 장소 명사의 목록은 Appendix 2에 제시하였다.

본 연구의 시각 자극은 사물의 이름대기, 식별 및 기억 과제에 컬 러사진이 효과적이라는 선행연구(Uttl, Graf \& Santacruz, 2006)에 근거하여 컬러사진으로 인화하였다. 노년층의 시지각적인 어려움 을 고려하여 $20.32 \times 25.4 \mathrm{~cm}$ 크기로 제작하였다(Appendix 3). 본 연구에서는 의미자질을 서술한 문장 단위의 글자카드를 사용하였 다. 중재 명사의 의미자질은 두산백과사전, 위키백과사전, 표준국 어대사전, 지식백과, 유네스코 세계문화유산 홈페이지를 참고하여 규모, 높이, 색상, 형태 등의 외형적(physical) 속성, 행정 구역 및 자 연 지리적인 위치, 기능적(functional) 속성이 포함되도록 옳은 의 미자질과 틀린 의미자질을 2 개씩 선정하였다(Appendix 4).

\section{중재 방법}

본 연구의 중재는 9단계로 진행되었다. 유명장소 이름대기 중재 는 선행연구(Kiran \& Thompson, 2003; Mo et al., 2015)의 SFA 중 재를 기반으로 총 9 단계로 구성되어 있다. 중재 절차와 방법을 Appendix 5에 제시하였다. 본 연구에서 적용된 이름대기 중재는 대상 자와 1:1로 1 회기 60 분 동안 이루어졌다. 중재는 일주일에 1-3회씩 8 주간 총 16 회기 이루어졌다. 매 회기 20 개의 중재 명사에 대해 중재 가 진행되며, 1 단계에서 이름대기 실시 후 대상자가 정반응한 경우
에도 1 단계부터 6 단계까지 모든 단계를 실시하였다. 6 단계에서 다 시 이름대기를 실시 후 대상자가 정반응하면 다음 중재 명사에 대 한 중재를 실시하였으며, 오반응하면 나머지 7단계부터 9단계의 중 재 절차를 진행한 뒤 다음 중재 명사에 대한 중재를 실시하였다. 중 재 1 단계의 정반응률이 3 회기 이상 $80 \%$ 를 넘으면 중재를 종료하였 다. 반면, 통제집단의 경우 사전 평가 과제 실시 후 사전 평가 과제 실시 전까지 중재 자극에 노출되지 않았다.

\section{사전·사후 평가 과제}

본중재 사전·사후 평가 과제로 유명장소 이름대기 과제와 K-BNT 를 실시하여 이름대기 능력 지표로 사용하였다. 유명장소 이름대 기 정반응률(\%)과 K-BNT의 점수(범위: 0-60)를 측정변수로 사용 하였다. 유명장소 이름대기 과제는 Microsoft Power Point를 활용 하여 컴퓨터 스크린에 한 슬라이드에 자극 하나를 배치하여 대상 자에게 제시하였다. 검사자는 선행연구(Brookshire, 1970)에 근거 하여 대상자에게 15 초를 부여하였고 시간이 초과되면 다음 문항으 로 넘어갔다. 사전 평가 과제 실시 후에는 정·오반응에 대한 피드백 을 제공하지 않았으나, 사후 평가 과제 실시 후에는 정·오반응에 대 한 피드백을 제공하였다.

\section{자료분석}

본 연구의 사전·사후 평가 과제로 실시한 유명장소 이름대기 과 제와 K-BNT의 대상자 반응을 기록하여 종속변수로 사용하였다. 대상자의 반응에 따라 정반응한 문항은 1 점, 오반응한 문항은 0 점 으로 계산하였다. 정반응의 기준은 Tranel 등(2005)의 연구에 근거 하여 정해진 시간 내에 목표 장소 이름을 정확히 산출한 경우이다. 다만, 자극에 따라 용인할 수 있는 다른 이름을 산출한 경우(예: 영 도대교-영도다리, 올림픽주경기장-잠실주경기장)를 정반응에 포 함하였다. 정반응한 문항의 수를 총 문항 수 40 으로 나눈 후 100 을 곱하여 정반응률(\%)을 계산하였다. 무반응, 반응 시간 초과, 틀린 이름, 상관없는 이름, 음소적 오류, 포괄적인 상위범주 사물 이름 (예: '불국사' 문항에 '절'이라고 반응), 의미자질 설명(파리에 있는 것), '모르겠다'는 반응 등은 오반응으로 분류하였다. 수집된 자료 는 IBM SPSS 26.0 을 이용하여 분석하였다. 사전·사후 평가 시 측 정한 종속변수의 정규성 검정을 위해 Kolmogorov-Smirnov test와 Shapiro-Wilk test를 실시한 결과, 각 종속변수들이 정규성을 충족 하여 모수 통계를 이용하여 분석을 실시하였다. 집단(중재집단 vs 통제집단)간 중재 전·후에 따른 유명장소 이름대기 및 K-BNT 수 행력의 차이를 검증하기 위하여 $2 \times 2$ 이원혼합분산분석(two-way mixed ANOVA)을 실시하였다. 


\section{연구결과}

사전·사후에 따른 유명장소 이름대기와 표준화검사인 K-BNT 수행력에 대하여 집단 간 차이가 있는지 알아보기 위해 집단과 시 간을 독립변수로 하고 이름대기 수행력을 종속변수로 하는 이원혼 합분산분석(two-way mixed ANOVA)을 실시하였다. 집단 간 사 전·사후에 따른 각 종속변수의 평균과 표준편차를 Table 4에 제시 하였다.

\section{집단 간 사전·사후에 따른 유명장소 중재 명사 이름대기 수행력 비교}

집단 간 사전·사후에 따른 중재 명사이름대기 수행력 비교를 위 한 이원분산분석 결과, 집단의 주효과가 통계적으로 유의하지 않 았다 $\left(F_{(1,24)}=3.627, p=.069\right)$. 반면, 중재 전·후 시간의 주효과가 통 계적으로 유의하였다 $\left(F_{(1,24)}=40.372, p<.001\right)$. 즉, 중재 후의 중재 명사 이름대기 정반응률이 중재 전의 정반응률에 비해 유의하게 높았다. 또 중재 전·후 및 집단 간의 유의한 상호작용이 나타났다
$\left(F_{(1,24)}=25.098, p<.001\right)$. 즉, 통제집단에 비해 중재집단에서 중재 전·후간 정반응률 차이가 유의하게 컸다. 중재명사 이름대기 수행 력에 대한 중재 전·후 시간 및 집단 간의 상호작용 효과는 Figure 1 과 같다.

\section{집단 간 사전·사후에 따른 유명장소 비중재 명사 이름대기 수행력 비교}

집단 간 사전·사후에 따른 비중재 명사 이름대기 수행력 비교를 위한 이원분산분석 결과, 집단의 주효과가 통계적으로 유의하지 않았다 $\left(F_{(1,24)}=.589, p=.450\right)$. 반면, 중재 전·후 시간의 주효과가 통 계적으로 유의하였다 $\left(F_{(1,24)}=6.434, p=.018\right)$. 즉, 중재 후의 비중재 명사 이름대기 정반응률이 중재 전의 정반응률에 비해 유의하게 높았다. 또 중재 전·후 시간 및 집단 간의 상호작용이 유의하였다 $\left(F_{(1,24)}=4.926, p<.05\right)$. 즉, 통제집단에 비해 중재집단의 사전 $\cdot$ 사후 평가 점수 차이가 통계적으로 유의하게 컸다. 비중재명사 이름대기 수행력에 대한 중재 전·후 시간 및 집단 간의 상호작용 효과는 Figure 2 와같다.

Table 4. Descriptive statistics on pre-post comparisons between groups on the landmark naming accuracy

\begin{tabular}{|c|c|c|c|c|c|}
\hline \multirow{2}{*}{ Dependent variables } & \multirow{2}{*}{ Group } & \multicolumn{2}{|c|}{ Pre } & \multicolumn{2}{|c|}{ Post } \\
\hline & & M & SD & $M$ & SD \\
\hline \multirow[t]{2}{*}{ Trained items (\%) } & Intervention & 52.27 & 23.49 & 80.45 & 22.07 \\
\hline & Control & 46.66 & 23.57 & 50.00 & 26.73 \\
\hline \multirow[t]{2}{*}{ Untrained items (\%) } & Intervention & 49.54 & 24.74 & 59.54 & 28.23 \\
\hline & Control & 46.66 & 23.65 & 47.33 & 25.13 \\
\hline \multirow[t]{2}{*}{ K-BNT (scores) } & Intervention & 49.18 & 6.52 & 50.90 & 7.94 \\
\hline & Control & 44.86 & 7.56 & 46.40 & 7.36 \\
\hline
\end{tabular}

KBPR= Korean Brief Parent Report; KBPRa= Early Milestones; KBPRb=Current Language Abilities; KBPRc= Behavior Patterns and Activity Preferences; KBPRd= Family History; NWR=Nonword Repetition; L_EB (S)=Linguistic Episodic Buffer (sentence order); L_EB (R)=Linguistic Episodic Buffer (randomized order); NL_EB (S)=Nonlinguistic Episodic Buffer (symmetric); NL_EB (A)= Nonlinguistic Episodic Buffer (asymmetric).

${ }^{*} p<.05,{ }^{* *} p<.01,{ }^{* * *} p<.001$.

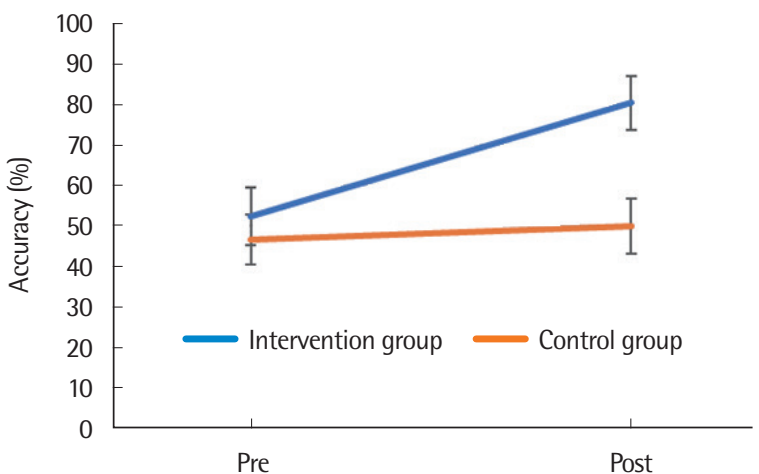

Figure 1. Two-way interaction between group and time on the naming test of trained items.

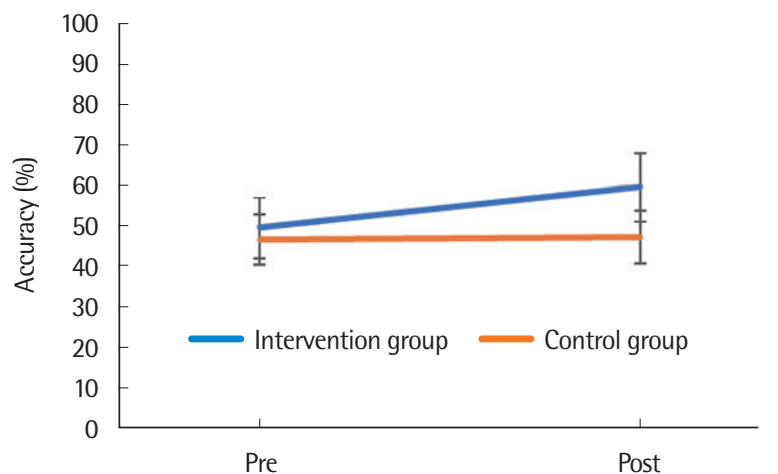

Figure 2. Two-way interaction between group and time on the naming test of untrained items. 


\section{집단 간 사전·사후에 따른 K-BNT 수행력 비교}

집단 간 사전·사후에 따른 K-BNT 수행력 비교를 위한 이원분산 분석 결과, 집단의 주효과가 통계적으로 유의하지 않았으나 $\left(F_{(1,24)}=\right.$ $2.337, p=.139)$, 중재 전·후 시간의 주효과가 통계적으로 유의하였 다 $\left(F_{(1,24)}=10.001, p<.005\right)$. 즉, 중재 전의 K-BNT 점수에 비해 중재 후의 K-BNT 점수가 유의하게 더 높았다. 중재 전·후 시간 및 집단 간의 상호작용 효과는 유의하지 않았다 $\left(F_{(1,24)}=.035, p=.852\right)$.

\section{논의 및 결론}

본 연구는 주관적 기억장애 노년층을 대상으로 유명장소 고유명 사에 대한 SFA 중재를 적용하여 (1)집단 간 사전·사후에 따른 중재 명사의 정반응률에 유의한 차이가 있는지 살펴보고, (2)집단 간 사 전·사후에 따른 비중재 명사의 정반응률에 유의한 차이가 있는지 살펴보았다. 또한 (3)집단 간 사전·사후에 따른 K-BNT 점수에 유 의한차이가 있는지 살펴보고자 하였다.

본 연구 결과를 요약하면 다음과 같다. 첫째, 유명장소 이름대기 중재 명사의 수행력에 대한 중재 전·후 및 집단 간의 상호작용이 통 계적으로 유의하였다. 즉, 통제집단과 비교하여 중재집단의 중재 전·후간 이름대기 수행력의 차이가 유의하게 컸다. 중재 결과로 대 상자들의 중재 단계에 직접적으로 적용된 고유명사 이름대기 수행 력이 향상된 것으로 볼 수 있다. 둘째, 비중재 명사의 수행력에서도 중재 전·후 및 집단 간의 상호작용이 통계적으로 유의하였다. 즉, 통 제집단에 비하여 중재집단의 중재 전·후 간 이름대기 수행력의 차 이가 유의하게 컸다. 중재 이름대기 단계에서 노출되지 않았던 고유 명사 이름대기로의 일반화 효과가 나타난 것으로 볼 수 있다. 그러 나사전-사후에 따른 집단 간 K-BNT 점수의 차이는 유의하지 않아 표준화검사에서 보통명사이름대기로의 일반화는 제한적이었다.

위와 같이 본 중재 연구는 주관적 기억장애 노년층의 이름대기 중재 효과와 비중재 명사로의 일반화 효과를 보고하였다. 이러한 결과가 도출된 이유는 다음과 같이 두 가지로 논의해 볼 수 있다.

첫째, SFA 중재가 목표 고유명사의 의미자질 산출을 촉진하고 중재 명사뿐만 아니라 중재 명사와 의미적으로 연결되어 있는 비중 재 명사의 의미 네트워크를 활성화시키는 데 효과적이었다고 볼 수 있다. 이 결과는 신경언어장애군을 대상으로 SFA 중재를 실시하여 중재 효과는 확인하였으나 일반화 효과는 제한적인 것으로 보고된 선행연구 결과(Kiran \& Thompson, 2003; Law et al., 2006; Kang et al., 2015; Mo et al., 2015)와 차이를 보이지만, 정상적인 인지능력을 가진 장-노년층을 대상으로 SFA 중재를 실시하여 이름대기 수행 력 개선을 보고한 선행연구(Kim et al., 2019) 결과와 일치한다. 본
중재는 의미범주 분류, 의미자질 분류 등의 의미적 접근을 통하여 중재 목표인 고유명사와 이와 의미적으로 연결된 비중재 고유명사 들의 의미자질 산출을 촉진하도록 계획되었다. 중재 자극 선정 단 계에서 의미적 연관성을 이루는 자극을 짝짓는 방식으로 균형을 맞추어 중재·비중재 명사를 선정·분류하여 제시한 것이 의미 네트 워크 활성화에 영향을 주었다고 볼 수 있다. 예를 들어, 대상자들이 중재 명사 '석굴암'의 이름대기 기회를 가지면서 '경주 관광지'라는 전반적인 의미 네트워크가 활성화되어 비중재 명사인 '불국사'의 이름대기에 성공하였다고 볼 수 있다. 또한, 중재 2 단계의 국내/해 외 명소의 의미범주 분류 과제를 통하여 물리적인 속성이 유사한 '개선문'과 ‘독립문' '63빌딩'과 ‘롯데월드타워' 등의 중재 · 비중재 명사의 시각적 자극에 지속적으로 노출되면서 시지각적 오류가 줄 고 두 자극의 의미자질 비교-대조가 유도되었다고 볼 수 있다. 중재 대상자 중 일부는 중재 회기 초반에 '스핑크스'를 '피라미드'로, '서 울법원청사'를 '국회의사당'으로 산출하며 이름대기에 혼동을 보였 으나 중재가 종료된 후 각 자극에 대하여 정반응을 보였다. 또한, 본 연구의 중재 3 단계에서 중재 명사에 대한 옳은 의미자질과 틀린 의 미자질을 제시하였는데, 이 때 의미적으로 연관된 비중재 명사의 의미자질을 중재 자극에 틀린 의미자질로 제시하였다. 대상자는 이 단계에서 비교·대조를 통해 의미자질을 강화하고, 의미적 네트워 크를 활성화시켰을 가능성이 있다. 예를 들어, '서울법원청사'와 '국 회의사당'은 의미적으로 '국가 주요기관'이라는 자질을 공유하고 있는데, 중재 시 '판사가 판결을 내리는 곳이다’와 '국회의원들이 회 의를 한다'의 기능에 대한 의미자질을 동시에 제시하여 의미자질의 비교·대조를 통한 의미 네트워크의 활성화를 유도하였다.

둘째, 본 중재의 음운·철자 단서가 노년층 이름대기의 음운 산출 의 어려움인 설단현상(tip-of-the-tongue; Brown \& McNeil, 1966; Burke et al., 1991)을 해결하여 이름대기를 촉진하는 데 효과적으 로 작용했을 것으로 보인다. 정상적인 인지능력을 가진 장·노년층 은 의미기억에서 의미 정보 인출, 의미표제어 선택까지의 과정은 정 상적으로 수행되나음운부호화에 실패하여 말하고자 하는 대상의 이름을 알고 있음에도 일시적으로 말이 혀끝에서 맴도는 설단현상 을 보이는 것으로 알려져 있다. 중재에 참여한 대상자들은 사진 자 극을 인식하면서 기억 속의 의미적 지식이 정상적으로 활성화되었 으나 음운 형태로의 접근의 어려움을 보이는 경우가 적지 않았다. 이들은 중재 1 단계 이후 이어지는 의미범주 분류, 의미자질 분류, 및 중재 명사 지도 위치 찾기 과제 등에서 모두 정반응을 보이면서 설단현상을 해결하기 위해 노력하는 모습이 두드러졌다. 대상자에 따라서는 개인적인 여행 경험을 구어로 산출하면서 '잘 알고 실제 로 다녀온 곳인데... 이름이 안 나오네'라며 당혹스러워하였다. 연구 
자는 중재 절차에 따라음절 수 단서를 우선 제시하였고 그 후 중재 명사 각 음절의 초성 글자 카드를 단서로 제시하였다. 예를 들어, '나이아가라'폭포의 음운정보 산출이 원활하지 않았던 대상자는 초성 카드 'ㄴ제시만으로도 정확한 이름대기를 수행하였다. 이러 한 음운 산출의 어려움은 해외 유명장소의 외래어 고유명사에서 두드러졌다.

위와 같이 중재에 포함된 유명장소 고유명사와 이와 의미적으로 연결된 비중재 명사에서 이름대기 수행력에 효과가 있었던 것에 반 하여, K-BNT로 측정한 사물 보통명사 이름대기로의 일반화 효과 가 없었던 이유는 다음과 같이 논의해 볼 수 있다. 우선, 본 연구의 대상자들은 객관적인 기억 손상이 없는 정상 노년층이며 K-BNT 결과에서 두 집단 모두 정상 범주의 이름대기 수행을 보였다. 따라 서 본 중재가 표준화검사에 대하여 유의한 효과를 미치지 못하여 천장효과(ceiling effect)를 보였다고 볼 수 있다. 또 다른 이유는 고 유명사 이름대기와 의미 네트워크에 보통명사와 다른 특성이 관여 하고 있을 가능성이다. 앞서 비중재 명사로 일반화가 나타난 것은 고유명사들이 서로 이루고 있는 의미 연관성으로 인한 것으로 논 의하였으나, 보통명사가 이루고 있는 의미 네트워크와 구별되는 고 유명사의 특성을 살펴볼 필요가 있다. 보통명사에 비해 고유명사의 인출이 더 복잡한데 그 이유로 고유명사의 특성의 하나인 지시대 상과 1:1로 대응하는 유일성을 들 수 있다(Robson et al., 2004). 일 반적인 사물 보통명사들이 다른 단어와 구별되게 하는(distinguishing) 의미자질을 가지고 있는 동시에 서로 복수의 공통적인 의미자질을 공유하며 위계적인 의미적 연결로 엮여 탄탄한 의미 네 트워크를 이루는 것과 대조되는 것이다. 의미 네트워크에서 고유명 사가 가지는 고유한 특성 및 구조가 보통명사의 의미 네트워크 활 성화에 영향을 미치기에 제한점으로 작용했을 것으로 볼 수 있다.

본 연구의 제한점 및 제언은 다음과 같다. 첫째, 본 연구의 대상자 수는 중재집단 11 명, 통제집단 15 명으로 총 26 명의 대상자가 연구 에 참여하였다. 이는 제한된 연구 대상자수로 인해 본 연구의 결과 를 일반화하는 데 한계가 있다. 따라서 각 집단 별 연구 대상자 수 를 확보하여 연구결과의 일반화를 구축할 필요가 있다. 둘째, 장소 고유명사라는 제한적인 중재 범주와 40 개라는 제한된 숫자의 중재 명사를 적용한 연구라는 한계가 있다. 또 장소 고유명사는 인공물 과 자연물 등을 비롯하여 다양한 의미자질로 구성되어 있으나, 본 연구에서는 중재 및 비중재 명사를 선정하는 과정에서 일부 의미 자질을 고려하여 중재 및 비중재 명사가 의미적 연관성을 가지도록 구성하였지만 중재 효과를 검증하는 과정에서 장소 고유명사를 구 성하는 의미자질의 영향은 살펴보지 못했다. 따라서 향후 장소 고 유명사의 의미자질을 구분하여 의미자질에 따른 이름대기 중재 효
과를 검증하는 연구가 이루어질 필요가 있다. 셋째, 본 연구는 중재 후 사후 평가를 진행하였으나 그 이후 평가가 이루어지지 않은 부 분이 제한점이라고 할 수 있다. 주관적 기억장애 노년층의 경우 시 간이 지남에 따라 수행력의 저하가 있을 수 있으므로 장기간에 걸 친 추적연구를 통해 중재 효과를 살펴보는 것이 필요할 것이다. 따 라서 향후 주관적 기억장애 노년층을 대상으로 장기간에 걸쳐 중 재 효과를 살펴본 종단연구가 진행될 필요가 있다.

\section{REFERENCES}

Ahmed, S., Arnold, R., Thompson, S. A., Graham, K. S., \& Hodges, J. R. (2008). Naming of objects, faces and buildings in mild cognitive impairment. Cortex, 44(6), 746-752.

Albert, M. S., Heller, H. S., \& Milberg, W. (1988). Changes in naming ability with age. Psychology and Aging, 3(2), 173-178.

Au R., Joung, P., Nicholas, M., Obler, L. K., Kass, R., \& Albert, M. L. (1995). Naming ability across the adult life span. Aging, Neuropsychology and Congnition, 2(4), 300-311.

Benthues, A., Leier, M., \& Maas, W. (2007). 100 Wonders of the world: the finest treasures of civilization and nature on five continents (W. H. Park, Trans.). Nederland, Rebo Publishers.

Boyle, M., \& Coelho, C. (1995) Application of semantic feature analysis as a treatment for aphasic dysnomia. American Journal of Speech-Language Pathology, 4(4), 94-98.

Brookshire, K. H. (1970). Comparative psychology of learning. In M. H. Max (Ed.), Learning: interactions (pp. 289-364). London: Macmillan Company. Brown, R., \& McNeill, D. (1966). The "tip of the tongue" phenomenon. Journal of Verbal Learning and Verbal Behavior, 5(4), 325-337.

Burke, D. M., MacKay, D. G., Worthley, J. S., \& Wade, E. (1991). On the tip of the tongue: what causes word finding failures in young and older adults? Journal of Memory and Language, 30(5), 542-579.

Burke, D. M., \& Shafto, M. A. (2004). Aging and language production. Current Directions in Psychological Science, 13(1), 21-24.

Chin, J., Oh, K. J., Seo, S. W., Shin, H. Y., \& Na, D. L. (2010). The characteristics and subtypes of subjective memory impairment in older adults. Dementia and Neurocognitive Disorders, 9(4), 115-121.

Cho, M. J., Bae, J. N., Suh, G. H., Hahm, B. J., Kim, J. K., Lee, D. W., \& Kang, M. H. (1999). Validation of geriatric depression scale, Korean version (GDS) in the assessment of DSM-III-R major depression. Journal of Korean Neuropsychiatric Association, 38(1), 48-63. 
ChosunBiz. (2016). Seoul Building Story. Retrieved from https://biz.chosun. com/site/data/html_dir/2016/10/16/2016101600450.html.

Christensen, K. J., Multhaup, K. S., Nordstrom, S., \& Voss, K. (1991). A cognitive battery for dementia: development and measurement characteristics. Psychological Assessment: A Journal of Consulting and Clinical Psychology, 3(2), 168-174.

Connor, L. T., Spiro, A., Obler, L. K., \& Albert, M. L. (2004). Change in object naming ability during adulthood. The Journals of Gerontology: Series B: Psychological Sciences and Social Sciences, 59(5), 203-209.

Condret-Santi, V., Barragan-Jason, G., Valton, L., Denuelle, M., Curot, J., Nespoulous, J. L., \& Barbeau, E. J. (2014). Object and proper name retrieval in temporal lobe epilepsy: a study of difficulties and latencies. Epilepsy Res. $108(10), 1825-1838$.

Evrard, M. (2002). Ageing and lexical access to common and proper names in picture naming. Brain and Language. 81(1-3), 174-179.

Faul, F., Erdfelder, E., Buchner, A., \& Lang, A. G. (2009). Statistical power analyses using $\mathrm{G}^{*}$ Power 3.1: tests for correlation and regression analyses. Behavior Research Methods, 41(4), 1149-1160.

Feyereisen, P. (1997). A meta-analytic procedure shows an age-related decline in picture naming: Comments on Goulet, Ska, and Kahn (1994). Journal of Speech, Language, and Hearing Research, 40(6), 1328-1333.

Hodges, J. R., \& Patterson, K. (1995). Is semantic memory consistently impaired early in the course of Alzheimer's disease? Neuroanatomical and diagnostic implications. Neuropsychologia, 33(4), 441-459.

Jessen, F., Amariglio, R. E., Van Boxtel, M., Breteler, M., Ceccaldi, M., Chételat, G., ... \& Subjective Cognitive Decline Initiative (SCD-I) Working Group. (2014). A conceptual framework for research on subjective cognitive decline in preclinical Alzheimer's disease. Alzheimer's \& Dementia, 10(6), 844-852.

Jo, H. L., \& Sung, J. E. (2019). Age-related differences in word recognition task according to the interference types: evidence from eye-tracking. Communication Sciences \& Disorders, 24(1), 186-204.

Kang, B. M. (2017). Topic semantic relation and network of Korean noun. Seoul: Hankook Publishing House.

Kang, J. Y., Sung, J. E., \& Lee, S. E. (2015). Effects of computerized language intervention on abilities of time-person-place orientation and naming for individuals with ddementia of the alzheimer's type. Communication Sciences \& Disorders, 20(2), 237-254.

Kang, Y. (2006). A normative study of the Korean-Mini Mental State Examination (K-MMSE) in the elderly. Korean Journal of Psychology: General,
25(2), 1-12.

Kang, Y., Jang, S., \& Na, D. L. (2012). Seoul neuropsychological screening battery, 2nd Edition (SNSB-II). Seoul: Human Brain Research \& Consulting Co.

Kaplan, E.F., Goodglass, H., \& Weintraub, S. (1983). The Boston Naming Test (2nd ed.), Philadelphia: Lea \& Febiger.

Kay, J., Hanley, R., \& Miles, R. (2001). Exploring the relationship between proper name anomia and word retrieval: a single case study. Cortex, 37(4), 501-517.

Kim, J., Kang, Y., Lee, H. Y., Kim, J., \& Yoon, J. H. (2019). Changes in naming and cognitive abilities as the effects of semantic feature analysis treatment in middle-aged and older adults. Communication Sciences \& Disorders, 24(1), 172-185.

Kim, M., Kwon, M., Lee, J, Sim, H. (2010). Impaired naming ability of famous people in patients with alzheimer's disease. Dementia and Neurocognitive Disorders, 9(3), 93-99.

Kiran, S., \& Thompson, C. K. (2003). The role of semantic complexity in treatment of naming deficits: training semantic categories in fluent aphasia by controlling exemplar typicality. Journal of Speech, Language, and Hearing Research, 46(4), 773-787.

Ku, H. M., Kim, J. H., Lee, H. S., Ko, H. J., Kwon, E. J., Jo, S., \& Kim, D. K. (2004). A study on the reliability and validity of Seoul-Activities of Daily Living (S-ADL). Journal of the Korean Geriatrics Society, 8(4), 206-214.

Law, S. P., Wong, W., Sung, F., \& Hon, J. (2006). A study of semantic treatment of three Chinese anomic patients. Neuropsychological Rehabilitation, 16(6), 601-629.

Lee, K. E., \& Lee, H. W. (2011). The effect of aging on retrieval of orthographic knowledge. Korean Journal of Cognitive and Biological Psychology, 23(4), 549-564.

Lee, K. M. (2000). Patterns of memory impairment. Annals of Clinical Neurophysiology, 2(2), 172-178.

Lee, M. S., \& Kim, H. (2011). Characteristics of expressive language in normal aging, mild cognitive impairment, and Alzheimer's disease. Dementia and Neurocognitive Disorders, 10(3), 69-79.

Levelt, W. J., Roelofs, A., \& Meyer, A. S. (1999). A theory of lexical access in speech production. Behavioral and Brain Sciences, 22(1), 1-38.

Minkina, I., Ojemann, J. G., Grabowski, T. J., Silkes, J. P., Phatak, V., \& Kendall, D. L. (2013). Treatment of proper name retrieval deficits in an individual with temporal lobe epilepsy. American Journal of Speech-Language Patholo$g y, 22(2)$. s250-255. 
Ministry of Health and Welfare. (2019). Plan for care economy fostering strategy. Sejong: Ministry of Health and Welfare.

Mo, K. O., Sung, J. E., \& Jeong, J. H. (2015). The effects of semantic feature analysis treatment on naming performance in Korean individuals with early dementia of the Alzheimer's type: using a familiarity of nouns scale. Communication Sciences \& Disorders, 20(1), 34-47.

Mortensen, L., Meyer, A. S., \& Humphreys, G. W. (2006). Age-related effects on speech production: a review. Language and Cognitive Processes, 21(13), 238-290.

Myerson, J., Ferraro, F. R., Hale, S., \& Lima, S. D. (1992). General slowing in semantic priming and word recognition. Psychology and Aging, 7(2), 257-270.

Neumann, Y., Obler, L. K., Gomes, H., \& Shafer, V. (2009) Phonological vs sensory contributions to age effects in naming: an electrophysiological study. Aphasiology 23(7-8), 1028-1039.

Oh, J. (2015). World heritage bible: Korea. Seoul: SangSang Publishing.

Oh, S. J., Eom, B., Park, C., \& Sung, J. E. (2016). Treatment efficacy of semantic feature analyses for persons with aphasia: evidence from meta-analyses. Communication Sciences \& Disorders, 21(2), 310-323.

Robson, J., Marshall, J., Pring, T., Montagu, A., \& Chiat, S. (2004). Processing proper nouns in aphasia: evidence from assessment and therapy. Aphasiology, 18(10), 917-935.

Ross, L. A., McCoy, D., Coslett, H. B., Olson, I. R., \& Wolk, D. A. (2011). Improved proper name recall in aging after electrical stimulation of the anterior temporal lobes. Frontiers in Aging Neuroscience, 3, 16.

Salthouse, T. A. (1996). The processing-speed theory of adult age differences in cognition. Psychological Review. 103(3), 403-428.

Snodgrass, J. G., \& Vanderwart, M. (1980). A standardized set of 260 pictures: norms for name agreement, image agreement, familiarity, and visual complexity. Journal of Experimental Psychology: Human Learning and Memory, 6(2), 174-215.

Song, M., \& Kang, Y. (2011). Characteristics of memory complaints, cognitive function, and emotion in subjective memory impairment (SMI). Dementia and Neurocognitive Disorder, 10(4), 125-136.

Tobiansky, R., Blizard, R., Livingston, G., \& Mann, A. (1995). The Gospel Oak Study stage IV: The clinical relevance of subjective memory impairment in older people. Psychological Medicine, 25(4), 779-786.

Tranel, D., Enekwechi, N., \& Manzel, K. (2005). A test for measuring recognition and naming of landmarks. Journal of Clinical and Experimental Neuropsychology, 27(1), 102-126.

Uttl, B., Graf, P., \& Santacruz, P. (2006). Object color affects identification and repetition priming. Scandinavian Journal of Psychology, 47(5), 313325

Won, S. R., Yoon, J. H., \& Na, D. L. (2017) Characteristics of confrontation naming ability according to word frequency in patients with amnestic mild cognitive impairment: a preliminary study. Communication Sciences \& Disorders, 22(2), 177-189.

Youn, J. C., Kim, K. W., Lee, D. Y., Jhoo, J. H., Lee, S. B., Park, J. H., ... \& Woo, J. I. (2008). Development of the subjective memory complaints questionnaire (SMCQ). Dementia and Geriatric Cognitive Disorders. 27(4), 310317. 
Appendix 1. 중재·비중재 명사 공통 의미자질 예시

\begin{tabular}{lll}
\hline 공통 의미자질 & 중재 명사 & 비중재 명사 \\
\hline 위치 & & \\
서울 & 명동성당 & 서울시청 \\
& 광화문 & 이순신장군 동상 \\
& 63빌딩 & 국회의사당 \\
& 올림픽주경기장 & 올림픽공원 \\
경주 & 석굴암 & 불국사 \\
부산 & 영도대교 & 태종대 \\
미국 & 백악관 & 자유의 여신상 \\
& 나이아가라 & 금문교 \\
프랑스 & 개선문 & 에펠탑 \\
이탈리아 & 피사의사탑 & 콜로세움 \\
이집트 & 스핑크스 & 피라미드 \\
중국 & 만리장성 & 천안문 \\
기능 & & \\
국가 주요시설 & 청와대 & 서울시청 \\
& 서울법원청사 & 국회의사당 \\
& 서울역 & 판문점 \\
기념물 및 문화·역사유적 & 타지마할 & 아크로폴리스 \\
& 앙코르와트 & 진시황릉 \\
& 오페라하우스 & 콜로세움 \\
자연명소 & 천지 & 성산 일출봉 \\
& 나이아가라 & 태종대 \\
물리적 속성 & & \\
대문 형태의 기념물 & 개선문 & 독립문 \\
고층빌딩 & 광화문 & 서울대정문 \\
& 63빌딩 & 롯데월드타워 \\
\hline & 무역센터 & 남산타워 \\
\hline & &
\end{tabular}


Sang Eun Lee, et al. • Effects of Naming Treatment in people with SMI

Appendix 2. 중재 명사 및 비중재 명사

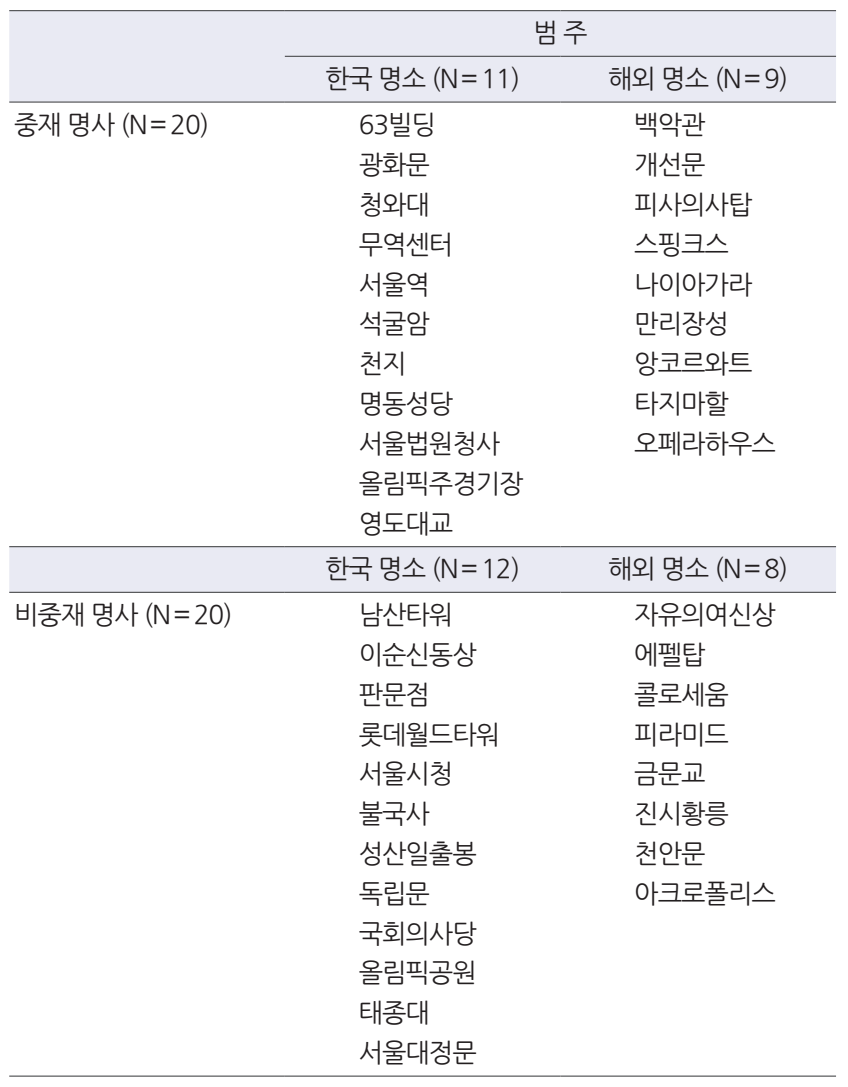


Appendix 3. 유명장소 사진자극 예시

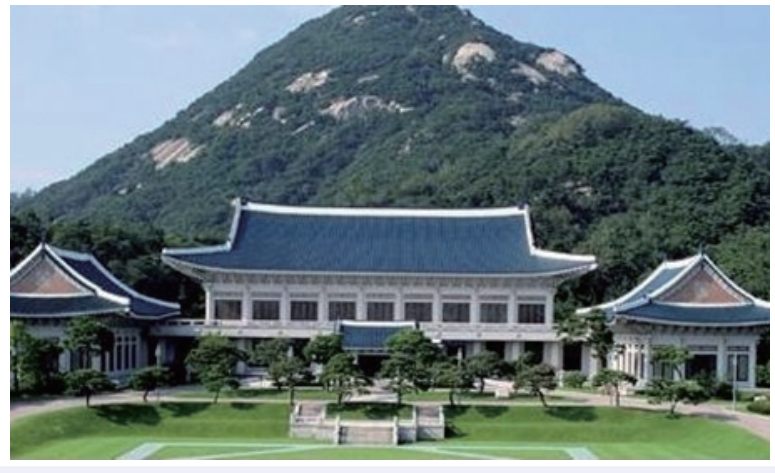

청와대

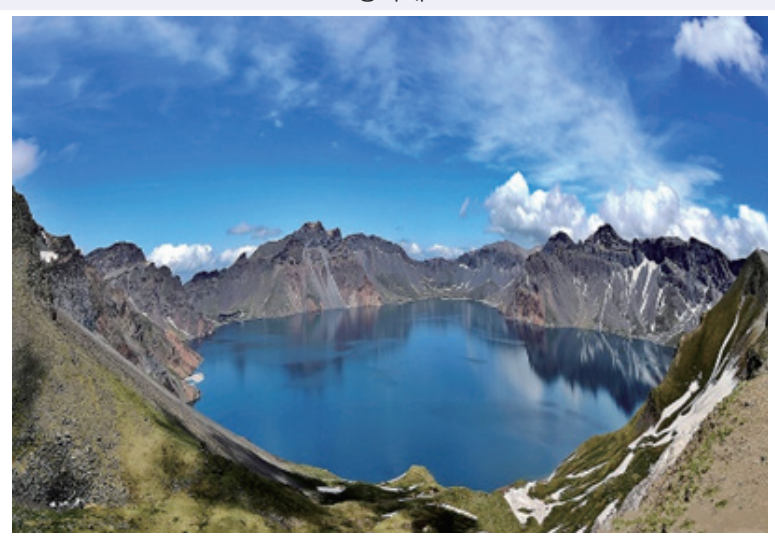

천지

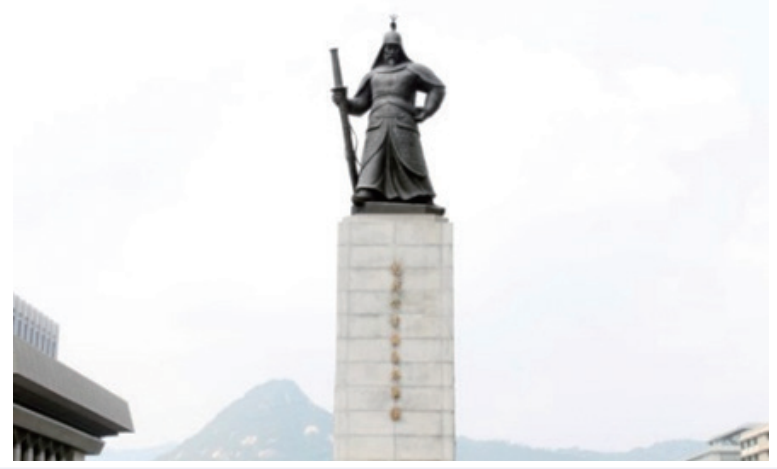

이순신장군 동상

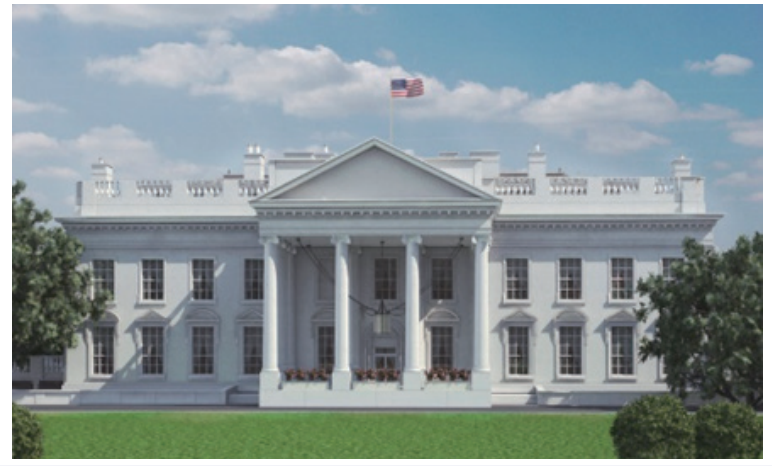

백악관

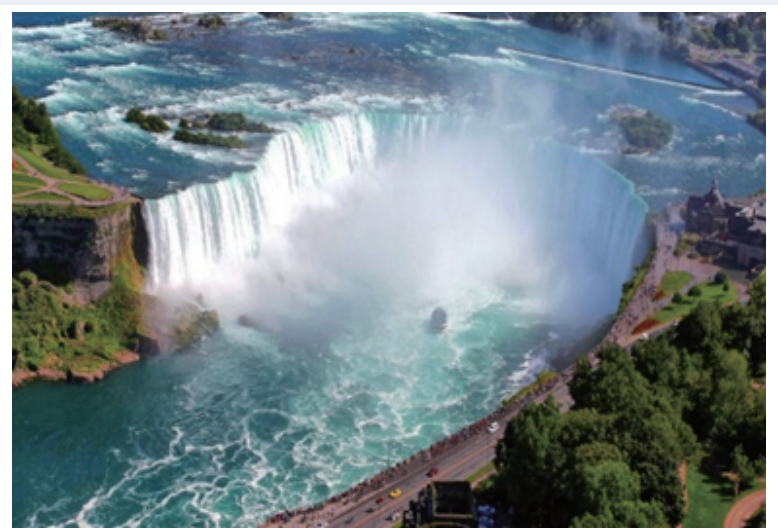

나이아가라 폭포

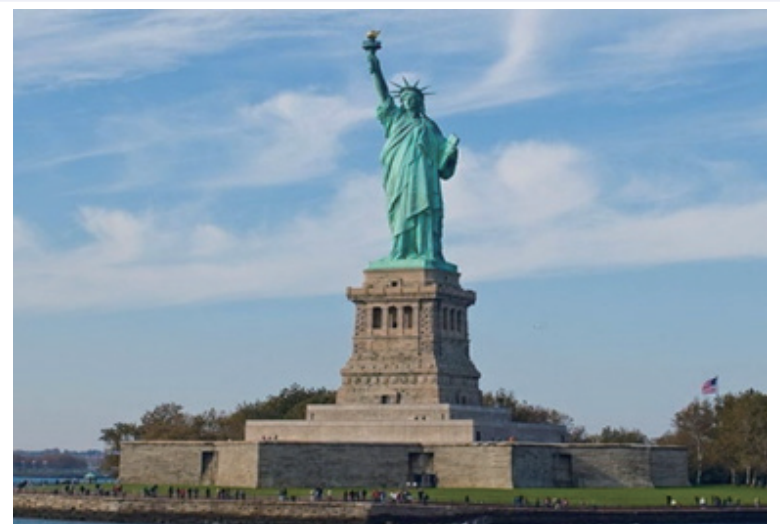

자유의 여신상 
Appendix 4. 중재 명사 의미자질

\begin{tabular}{|c|c|c|c|c|}
\hline \multirow{3}{*}{$\begin{array}{l}\text { 국내 장소 } \\
\text { 63빌딩 }\end{array}$} & \multicolumn{4}{|c|}{ 의미 자질(물리적 속성, 지리적 위치, 행정 구역 및 기능) } \\
\hline & \multicolumn{2}{|c|}{ 옳은 의미자질(O) } & \multicolumn{2}{|c|}{ 틀린 의미자질 $(X)$} \\
\hline & 황금빛 고층 빌딩이다 & 서울 여의도에 있다 & 지상 23층이다 & 서울 잠실에 있다 \\
\hline 광화문 & 세개의 붉은색 문이 있다 & 궁궐의 출입구이다 & 지붕에 뾰족한 종탑이 있다 & 중국 북경에 있다 \\
\hline 청와대 & 푸른 기와 지붕이 있다 & 대통령이 머물며 업무를 본다 & 푸른 둥근 돔형 지붕이 있다 & 서울 여의도에 있다 \\
\hline 무역센터 & 계단 디자인의 대형 빌딩이다 & 서울 삼성동에 있다 & 돌로 쌓아 올렸다 & 미국 뉴욕에 있다 \\
\hline 서울역 & 붉은색 벽돌로 벽을 쌓았다 & 기차가 출발. 도착한다 & 한국 전통 방식으로 지었다 & 재판을 하는 곳이다 \\
\hline 석굴암 & 돌로 만든 석가모니 상이다 & 경주에 있다 & 횃불을 든 여인의 형상이다 & 고대 중국의 무덤이다 \\
\hline 천지 & 산 정상에 있는 호수이다 & 백두산에 있다 & 농작물을 키우는 곳이다 & 제주도에 있다 \\
\hline 명동성당 & 뾰족한 탑과 지붕이 있다 & 서울 명동에 있다 & 기와 지붕의 목조 건물이다 & 불교 유적이다 \\
\hline 서울법원종합청사 & 중앙에 원기둥 2개가 있다 & 판사가 판결을 내리는 곳이다 & 벽면에 알록달록한 무늬가 있다 & 국회의원들이 회의를 한다 \\
\hline 올림픽주경기장 & 운동장과 운동 경기를 보는 자리가 있다 & 서울 잠실에 있다 & 지붕으로 덮여 있다 & 부산 해변에 있다 \\
\hline 영도대교 & 다리가 위로 들려 올라간다 & 부산에 있다 & 비행기가 출발하는 길이다 & 서울 한강에 있다 \\
\hline \multirow{2}{*}{ 해외 장소 } & \multicolumn{4}{|c|}{ 의미 자질(물리적 속성, 지리적 위치, 행정 구역 및 기능) } \\
\hline & \multicolumn{2}{|c|}{ 옳은 의미자질 ( O ) } & \multicolumn{2}{|c|}{ 틀린 의미자질 $(X)$} \\
\hline 백악관 & 흰색 벽과 지붕이 있다 & 미국 대통령의 집무실이 있다 & 벽과 지붕에 금색 장식이 있다 & 유럽에 있다 \\
\hline 개선문 & 곡선(아치) 형태의 거대한 문이다 & 프랑스 파리에 있다 & 돌기둥 여러 개가 둘러싸고 있다 & 영국 런던에 있다 \\
\hline 피사의사탑 & 기울어져 비스듬하게 서 있다 & 유럽 이탈리아에 있다 & 철기둥이 겉으로 드러나 있다 & 미국에 있다 \\
\hline 스핑크스 & 사람머리 형상의 석(돌)상이다 & 이집트 사막에 있다 & 사람들이 모여 운동 경기를 본다 & 중국에 있다 \\
\hline 나이아가라 & 큰 물줄기가 쏟아진다 & 미국과 캐나다 사이에 있다 & 해안가 절벽이다 & 아프리카에 있다 \\
\hline 만리장성 & 길고 튼튼한 성벽이 있다 & 중국에 있다 & 둥근 지붕이 있다 & 바닷가에 있다 \\
\hline 앙코르와트 & 둥글게 쌓아올린 돌탑들이 있다 & 동남아시아에 있다 & 높은 흰색의 뾰족한 탑이다 & 유럽 이탈리아에 있다 \\
\hline 타지마할 & 둥근 양파 모양의 흰색 지붕들이 있다 & 인도에 있다 & 목재를 쌓아 지었다 & 외적을 막기 위한 군사시설이다 \\
\hline 오페라 하우스 & 조개 껍데기 모양의 지붕이 있다 & 호주 시드니에 있다 & 편평한 지붕의 상자 모양이다 & 중국 상하이에 있다 \\
\hline
\end{tabular}


Appendix 5. 중재 절차 및 방법

\begin{tabular}{ll} 
단계 & 방법 \\
\hline 1단계 & 이름대기 \\
& 중재 명사 사진 자극 1장을 가운데 두고 이름대기 유도 \\
-오반응 시 피드백 없음 &
\end{tabular}

2단계 의미범주 분류

'국내/해외명소'카드 아래 중재 자극 1장과 전체 자극에서 무작위로 추출한 유명장소 사진 5 장, 총 6 장을 범주에 따라 분류하도록 유도

-오반응 시 피드백 제공

-비중재 명사도 제시

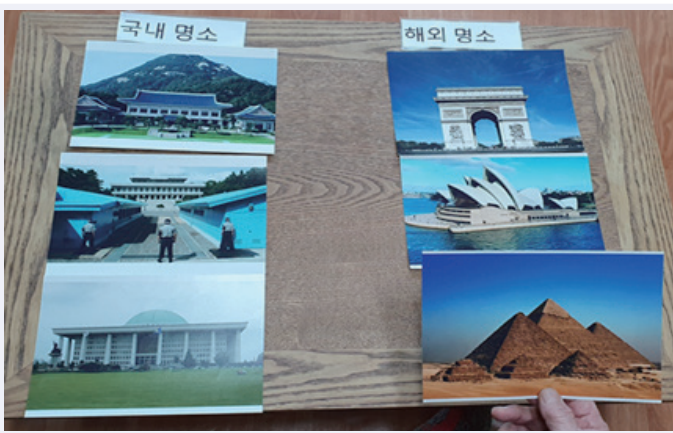

3단계 의미자질 $\mathrm{O} / \mathrm{X}$ 분류

중재 명사 사진 자극 1 장을 가운데 두고 중재 명사에 관련된 의미자질 글자 카드를 4 개 제시하고 옳고 틀린 자질을 분류

-오반응 시 피드백 제공
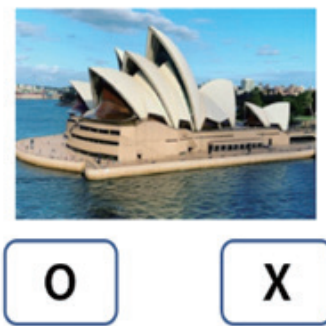

호주 시드니에 있다

중국 상하이에 있다

조개 껍데기 모양의 지붕이 있다 편평한 지붕의 상자모양이다

4단계 '예/아니오' 질문

중재 명사 사진 자극 1 장을 가운데 두고 의미 자질의 '예/아니오' 질문을 하고 대답 유도

-오반응 시 피드백 제공

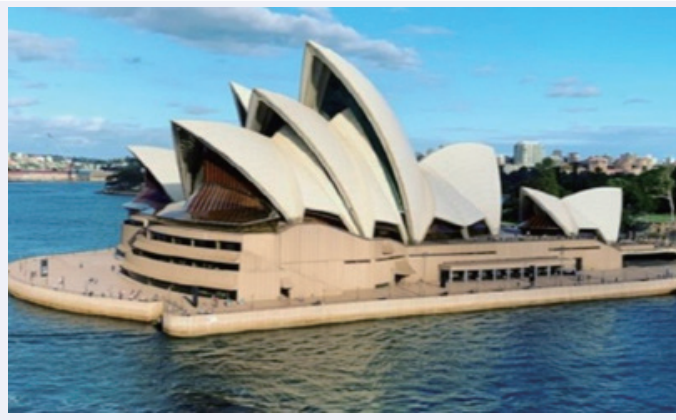

(Continued to the next page) 
Sang Eun Lee, et al. • Effects of Naming Treatment in people with SMI

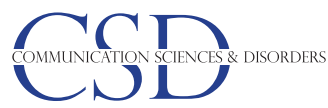

Appendix 5. Continued

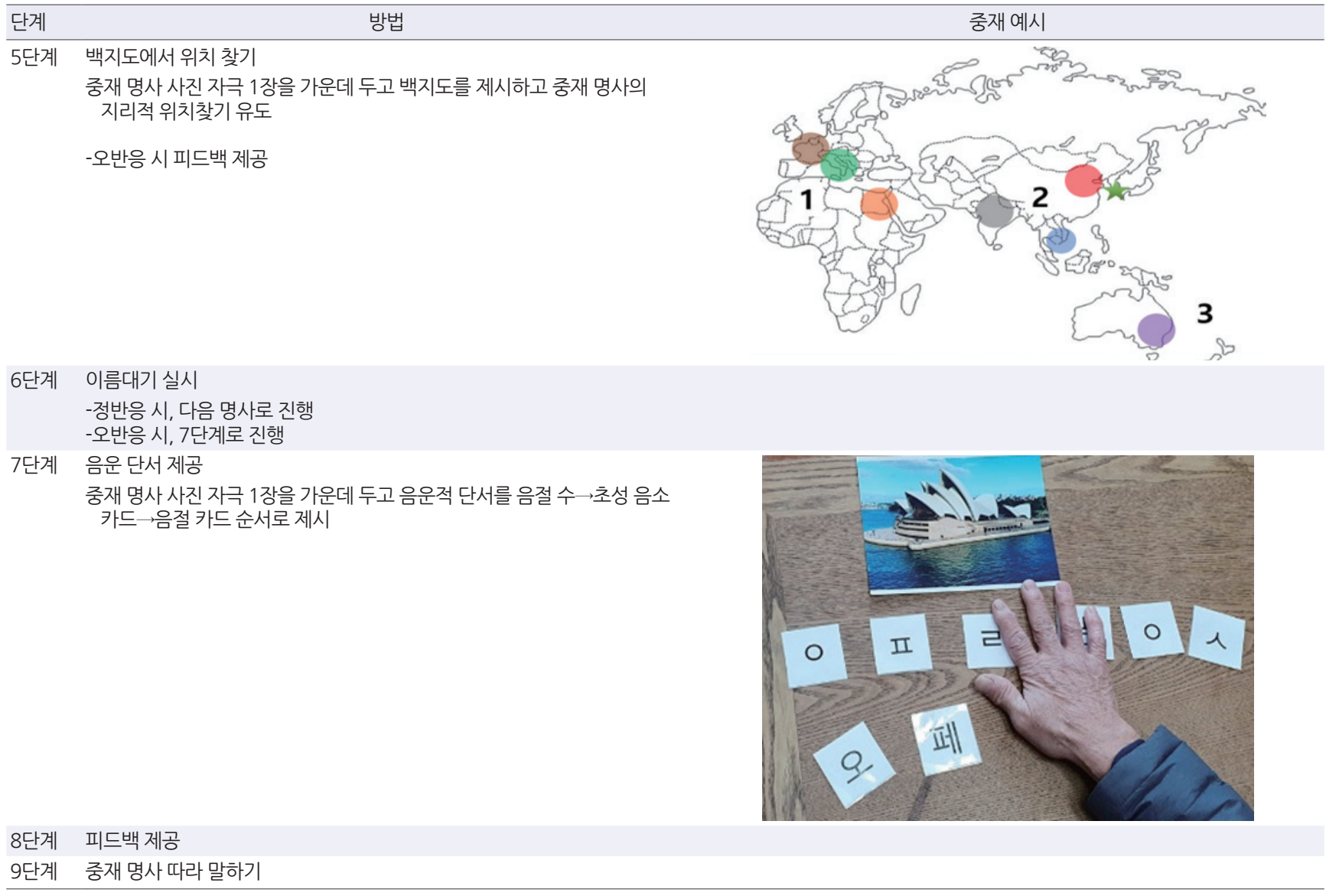




\section{국문초록}

\section{의미자질(SFA) 중재가 주관적 기억장애 노년층의 유명장소 이름대기 능력에 미치는 효과 이상은 · 성지은 · 조은하 \\ 이화여자대학교 대학원 언어병리학과}

배경 및 목적: 기억저하(memory decline) 등 인지 기능의 변화를 호소하는 노년층이 겪는 대표적인 언어적 어려움을 고유명사 이름대 기(proper noun naming)로 설정하고 언어 중재를 적용한 후 중재 명사 이름대기 수행력에 미치는 효과와 비중재 명사 및 표준화검사로 의 일반화 효과를 규명하였다. 방법: 주관적으로 기억력 저하를 호소하지만 객관적인 인지 기능에서 정상 범주의 수행을 보이는 만 60 세 이상의 노인 26 명을 선정하였다. 11 명의 중재집단과 15 명의 통제집단이 본 연구에 참여하였으며, 고유명사 이름대기 중재는 대상자 와 $1: 1$ 로 1 회기 60 분 동안 16 회기에 걸쳐 이루어졌다. 의미자질분석 중재를 기반으로 총 9 단계로 구성되었으며 이름대기 수행을 촉진하 기 위하여 시각적 자극, 의미범주, 의미자질 분석, 지리적 위치, 음운 · 철자 단서 등의 요소를 적용하였다. 결과: 유명장소 이름대기 중재 명사의 수행력에 대한 중재 전· 후 및 집단 간의 상호작용이 유의하였다. 유명장소 이름대기 비중재 명사의 수행력에 대한 중재 전 · 후 및 집단 간의 상호작용이 유의하였다. 중재집단과 통제집단 간 보스턴이름대기검사 점수를 비교한 결과, 표준화 이름대기 검사로의 일 반화 효과는 나타나지 않았다. 논의 및 결론: 의미자질 중재(SFA)가 목표 고유명사의 의미자질 산출을 촉진하고 중재 명사뿐만 아니라 중재 명사와 의미적으로 연결되어 있는 비중재 명사의 의미 네트워크를 활성화시키는 데 효과적이었다고 볼수 있다.

핵심어: 의미자질(SFA) 중재, 주관적 기억장애(SMI), 고유명사 이름대기

본 연구는 대한민국 교육부와한국연구 재단의 지원을 받아 수행된 연구임(No. NRF-2019R1A2C1089280).

본 논문은 제1저자(이상은)의 석사학위논문을 발췌 및 수정한 것임.

\section{참고문헌}

강범모 (2017). 한국어 명사의 화제 의미관계와 네트워크. 서울: 한국문화사.

강연욱 (2006). K-MMSE (Korean-mini mental state examination)의 노인 규준 연구. 한국심리학회지: 일반, 25(2), 1-12.

강연욱, 장승민, 나덕렬 (2012). 서울신경심리검사 2 판 (SNSB-II). 인천: 휴브알엔씨.

강지윤, 성지은, 이수은 (2015). 컴퓨터프로그램을 활용한 알츠하이머성 치매환자의 지남력 및 명사 이름대기 중재 효과. Communication Sciences

\&Disorders, 20(2), 237-254.

구형모, 김지혜, 이형석, 고혜정, 권의정, 안상미, 김도관 (2004). 일상활동평가-복합의 신뢰도 및 타당도 연구. 대한노인병학회, 8(4), 206-214.

김미정, 권미선, 이준영, 심현섭 (2010). 알츠하이머 치매환자의 유명인이름대기 능력 손상 연구. Dementia and Neurocognitive Disorders, 9(3), 93-99. 김정완, 강연욱, 이호영, 김재현, 윤지혜 (2019). 의미자질분석 중재에 따른 장노년층의 이름대기 및 인지능력 변화. Communication Sciences \& Disorders, 24(1), 172-185.

모경옥, 성지은, 정지향 (2015). 명사 친숙도를 활용한 의미자질중재가초기 알츠하이머성 치매노인의 이름대기 능력에 미치는 효과. Communication

Sciences \& Disorders, 20(1), 34-47.

보건복지부 (2019). 돌봄 경제(Care Economy) 육성전략 수립 계획(안). 세종: 보건복지부.

송민지, 강연욱 (2011). 주관적 기억장애의 기억문제 호소 양상과 인지기능 및 정서 특성. Dementia and Neurocognitive Disorders, 10(4), 125-136.

Anne Benthues, Manfred Leier, \& Winfried Maas. (2007). 세계에서 가장 경이로운 자연·문화 유산 100: 문명과 자연이 빚은 놀라운 걸작들(박웅희

역). 파주: 서강.

오세진, 엄보라, 박채원, 성지은 (2016). 실어증 환자를 위한 의미자질 이름대기 중재 효과에 관한 메타 분석. Communication Sciences \& Disorders,

21(2), 310-323. 
오주환 (2015). 세계문화유산 100배 즐기기: 한국편. 서울: 상상출판.

원새롬, 윤지혜, 나덕렬 (2017). 단어 빈도에 따른 기억성 경도인지장애 환자의 대면이름대기 특성: 예비연구. Communication Sciences \& Disorders, 22(2), 177-189.

이경민 (2000). 기억기능장애의 양상. 대한임상신경생리학회지, 2(2), 172-178.

이고은, 이혜원 (2011). 철자 정보산출에서 노화의 영향. 한국심리학회지: 인지 및 생물, 23(4) 549-564.

이미숙, 김향희 (2011). 정상노년층, 경도인지장애, 알츠하이머성 치매의 언어 산출 특성. Dementia and Neurocognitive Disorders, 10(3), 69-79.

조맹제, 배재남, 서국희, 함봉진, 김장규, 이동우, 강민희 (1999). DSM-III-R 주요우울증에 대한 한국어판 Geriatric Depression Scale (GDS)의 진단적 타당성 연구. 신경정신의학, 38(1), 48-63.

조선비즈 (2016). 서울 빌딩 스토리. 서울: 조선비즈.

조혜련, 성지은. (2019). 시선추적을 활용한 방해자극 유형에 따른 단어재인 과제에서 청년층과 노년층 간 수행력 비교. Communication Sciences \&

Disorders, 24(1), 186-204.

진주희, 오경자, 서상원, 신희영, 나덕렬 (2010). 노인의 주관적 기억 장애의 특징 및 하위 유형. Dementia and Neurocognitive Disorders, 9(4), 115-

121.

\section{ORCID}

이상은(제1저자, 대학원생 https://orcid.org/0000-0002-3824-5850); 성지은(교신저자, 교수 https://orcid.org/0000-0002-1734-0058);

조은하(공동저자, 대학원생 https://orcid.org/0000-0003-2472-5690) 